International Journal of

Economic Policy

in Emerging

Economies 


\section{International}

\section{Journal of}

\section{Economic Policy}

\section{in Emerging}

○

\section{Economies}

Volume 9, No. 2, 2016

Publisher's website: wwwilnderselance com

Email: editorial@inderscience.com

ISSN (Print) $1752-0452$

ISSN (Online) 1752-0460

Copyrighto 2016 Inderscience Enterprises I tu

No par of this publication may be reprodueed shorad no wanamitred un any material form or by any means (including electronic not hariug at pholocopying, recording or otherwise) wilhoul tlio phor willen permission of the publisher, except in accordance with llir previatiofts of the Copynight Designs and Patents Act 1003 or ufteder the temir of a licence issued by the Copyright Licensing Agency I ld or Ihe Gooynohn Clearance Center Inc

Pubtshed and typeset in the UK by Inderncience Itnleiprines LiI 


\section{Contents}

\section{SPECIAL. ISSUE: MIUTH-FACETEU ANALYSES ON EMERGING ECONOMIES' SUSTAINABLE DEVELOPMENT}

Guest Editors: Professor Michael K. Fung and Professor Bruno S. Sergi

101 Fditorial

Michael K. Fung and Bruno S. Sergi

103 Financial development and economic growth: the cases of Thailand, Malaysia, and the Philippines

Oramuch Wongpiabovorn

127 An assessment of competitiveness in emerging Asian economies with special reference to India

Aswini Kumar Mishra, Ganesh Rao and Bhargav Vishwanoth

145 'Bakulan R1 36', web media for supporting women's economic empowerment in Yogyakarta

Dhwah Ayu Remo Widuastuif, F. Anita Herawait, Theresia Diyah Wulondari. Pupung Arifin and Yonathan Dri Handarkho

158 Comparative study on regulatory requirements on corporate social responsibility in A ustralia and Thailand

Pornchai Wisuttisak and Chompunoor Wisuftisak

169. Evaluation of the reproduction processes in farms in Poland in context of the environmental and economic sustainability Aleksander Grzelak

182 The role of public sector expenditure on local economic development Mohamad Khusaini 


\title{
'Bakulan Rt 36', web media for supporting women's economic empowerment in Yogyakarta
}

\author{
Dhyah Ayu Retno Widyastuti*, \\ F. Anita Herawati, \\ Theresia Diyah Wulandari and Pupung Arifin
}

Communication Department, Faculty of Social and Political Sciences, Atma Jaya Yogyakarta University, Jl. Babarsari No. 4 Yogyakarta, Indonesia Email: ayu_cahindu@yahoo.com Email: ayucahindu@gmail.com Email: anita_hcra@yahoo.com Email: wulandari@mail.uajy.ac.id Email: pupung.arifin@yahoo.com *Corresponding author

\section{Yonathan Dri Handarkho}

Informatics Engineering Department, Faculty of Informatics Engineering, Atma Jaya Yogyakarta University, J1. Babarsari No. 4 Yogyakarta, Indonesia Email: yonathan_dh(a)staff.uajy.ac.id

\begin{abstract}
Wumen empowcrment is one of the 2015 MDG goals. In the current digital tia, all proccsses are eased by ICT usages. The World Bank in 2002-2009 reported that Indonesia has $87 \%$ total internet access population with a small number appliced to supporting economic activities, including women. The study has been courducted at Kunnumg Cyber RT 36. It conducted deep analysis on PAR method on the participation of men and women as an integral part. The research programme is going to luold problcm solving due to research subject needs (Mikkclscn, 2001), while gender perspectives is applied to solve the research problem. Diffusion innovation theory is chosen as the reality framework (Rugers, 1995). The tesult of our study shows that there is a way to develop wornen capacity. Based on need assessment of the target groups, the team held programmes such as training programme and build website prototype to promote their businesses. It created 'Bakulan RT 36'.
\end{abstract}

Keywords: Yogyakarta; web media; ICT; women communities; economic empowerment.

Reference to this paper should be made as follows: Widyastuti, D.A.R., Herawati, F.A., Wulandari, T.D., Arifin, P. and Dri Handarko, Y. (2016) 'Bakulan Rt 36', web media for supporting women's economic empowerment in Yogyakarta', Int. J. Economic Policy in Emerging Economies, Vol. 9, No. 2, pp.145-157. 
Biographical notes: Dhyah Ayu Retno Widyastuti is a Lecturer in Communication Science Department at University of Atma Jaya, Yogyakarta (UAJY). Her main areas of research and society empowerment interests include gender and women empowerment issue, advertising and marketing communications.

F. Anita Herawati is a Lecturer in Conmunication Science Department at University of Atma Jaya, Yogyakarta. She has conducted some research related to the tourism village and the empowerment of women. She also has an interest in the study of entrepreneurship, advertising and marketing communications.

Theresia Diyah Wulandari is a Lecturer in Communication Science Department at University of Atma Jaya, Yogyakarta. She has conducted some research related to ICT-based social and cultural communication and the empowerment of women. She also has an interest in the study of public relations, journalistic, marketing management, and communication management.

Pupung Arifin is a Lecturer in Communication Science Department at University of Atma Jaya, Yogyakarta. He has done some researches and society empowerment. His main areas of interests include online journalism ethics, online news portal, and media literation.

Yonathan Dri Handarkho is a Lecturer in Informatics Engineering Department at University of Atma Jaya, Yogyakarta. He has conducted some research related to relationship management and the empowerment of women through ICT. He also has an interest in the study of enterprise information system.

This paper is a revised and expanded version of a paper entitled "Bakulan Rt 36" As a media based on ICT to support women's economic empowerment (The study on woman communities in Kampung Cyber Rt 36 - Taman Sari, Yogyakarta)' presented at 2014 SIBR Conference on Interdisciplinary Business and Economics Research, Bangkok, 5-7 June 2014

\section{Introduction}

Providing information access is important for everyone's lives. One of the facilities used to spread information to society is media. Media plays the rolc as a channel to deliver messages in many different ways - from conventional media to contemporary one. The dynamics of media development is also getting more advanced and a perfect time comes for media based on ICT to be used in daily life. Rogers (1986) states that communication technology is a hardware containing social values, which allow every person to collect process and exchange information with other individuals. A computer equipped with internet network eases people to accomplish their jobs.

An ideal thing is every person can access the media. However, the fact speaks differently when it comes to internet-based media. The tendency is for some parts of society to face difficulties in accessing, operating, and taking advantages of the internet to support their productive business activities. This fact can be observed among residents of Kampung Cyber, Sub-District Patehan, Yogyakarta (Herawati et al., 2013). Specificaliy in Yogyakarta, it is noted that there are only $5 \%$ of women who are able to use the facility out of $52 \%$ residents who have computers and internet access. The gap in 
accessing information thru media is caused by several factors. In terms of difficulties faced by women in accessing information technology, they are affected by internal factors which comes from the women themselves and external factor which tends to be limited by nearby residency, mainly its closeness with the Palace area (Herawati et al., 2013).

The residents of Kampung cyber have autonomous business which can be developed to build independency and empowerment on women such as Batik craft, T-shirt printing, convection, and other hand-made products. Besides, there is availability of network media facility and it can be used for public. In progress, this technology can be used for society empowerment through many kinds of business. For example, based on a case study in UK, ICT is applied to build identity and empowerment on woman refugees (Siddiquee and Carolyn, 2006). A different picture is shown in the research conducted by Rhodes and Rural Women's Association (RWA) in Sekhuhkuneland - South Africa, ICT is applied to empower women potentials and improve the economic conditions of the members by enlarging the marketing of small business they manage (Rhodes, 2003).

Based on this fact, the writer has an opportunity to create a programme related to the problems and needs of society in Yogyakarta. Furthermore, the programme starts from need assessment in woman group of Kampung Cyber. In this step, the writer gained data that there are difficulties faced by women in accessing internet. Based on this finding, the writer creates a training programme which shares the importance of computer, the usage of computer which includes Microsoft Word and Microsoft Excel, the usage of internet to support productive business activities. As the output of training, the writer creates a media to facilitate women in introducing and selling their works towards wider society. It is expected that they can improve economic capacity equipped with ICT-based facility in line with the challenge of industry world in this digital era. Specifically, the media created is the website http://www.bakulanit36.com.

\section{Review of literature}

This study emphasises on media as a facility to empower people. Through media, much information can be accessed; media can strongly spread information to the society. Some studies related to women empowerment and ICT are:

1 women and internet access (study on the factors affecting the limited internet access on women in Yogyakarta)

2 the use of ICT as media for women empowerment in special province of Yogyakarta.

This writing emphasises on an output aspect of the programme and concepts used as analysis are related to media development, women involvement, and community literacy based on digital media.

\subsection{Media based on ICT}

Media is one of the aspects in communication activity which plays the role as information channel to facilitate both in sending and receiving information. At present, media development is an interesting dynamic in the communication context and in a short time changes on services can be made. Its implication is media influences the way people 
manage their time and therefore it affects the social values of society. This development starts from conventional and contemporary media up to the development of information and communication which reveals a new media based on the internet. This internet-based media is getting familiar to the lives of society through facilities which ease in accessing information.

The internet stands for interconnection-networking. It is a wide group of networking of big and small computers connected by communication network all over the world. The networks have differences in its both operating system and application, in which they take advantage of communication development (phone and satellite) which uses standard protocol in communication: TCP/IP protocol or Transmission Control//nternet Protocol (Supriyanto, 2008). Computer equipped with internet enables the users to freely communicate with other users in the world. Internet service now can easily be accessed through various gadgets like smart phone and hand phone. It means the existence of those gadgets creates consumptive culture in terms of internet consumption.

The usages of network-based media are as a learning media and business service. This fact can be observed in the developing of e-learning course model through

1 web course - internet as long distance learning media

2 web centric course - internet needed for a combination of face-to-face and long distance learning

3 web enhanced course - internet to support class learning (Rusman, 2007).

Besides, internet bridges efforts in achieving social welfare. One of them is in transactions through internet network known as electronic commerce (e-commerce). For example, a business run by RWA in Sekhuhkuneland - South Africa empowers women potentials and increases the economic capacities of its members by widening the marketing of their small businesses through the use of ICT (Rhodes, 2003). Furthermore, internet-based ICT is also adopted by small business actors or UKM (Rosnafisah et al., 2002; Herawati et al., 2013).

This condition shows that the use of internet-based ICT has been a vital part of a country development. Due to this reason, the society put efforts to build inclusive communities towards digital world.

\subsection{Community literacy}

Community literacy, which has been known since 15 years ago, at the beginning was secn as the exclusivity of culture literacy. Then, analysis change was promoted by Gabrill (2001) that says community literacy is the encouragement for individual or community to seek for and gain wider professions in the public area. In the next era, community literacy refers to all literacy practices involving family and society to organise people actions in

a using writings to support collaborative investigation on society problems

b inviting local people near the target of research applying democratic procedures

c changing personal knowledge through open dialogues between multicultural individuals and groups (Herawati et al., 2013).

At the beginning, the community literacy had been developed by Mills (1987), through previous programmes such as non-academic and non-workplace 'sponsor of 
literacy', known as labour market intermediaries (LMIs). LMIs are companies working for mediating the employers and their employees such as government-sponsored unemployment centres, temporary cmployment agencies, and community centre (see Table 1).

Table 1 Types of LMIs

\begin{tabular}{lc}
\hline Organisation types & Examples \\
\hline For-profit sector & Temporary agencies and for-profit training providers \\
Contractor brokers & Professional employer organisation \\
Online job search-websites \\
Union-based initiatives \\
Membership-based \\
Public sector \\
Membership-based employee associations \\
Employment training and workforce development \\
System (one stop career centres) \\
Education-based initiatives (adult extension, community college contract \\
training programine) \\
Non-profit initiatives (publicly or privately funded training programme)
\end{tabular}

Source: Mills (1987)

Referring to Table 1, the writer's programme is based on facts in public sectors which work on educational movements specifically aiming at society empowerment. This programme is a non-profit movement by providing trainings for society.

Empowerment refers to widening freedom in choosing and taking actions. Sumodiningrat (1997) states that society empowerment includes two related groups - the under-developed society as the group needs to be empowered and certain groups of society who empower. Empowerment is a process in which a series of activities strengthen the power of weak groups in society. Generally, the elements of people empowerment are:

1 inclusion and participation

2 access to informalion

3 local organisation capacity

4 professionalism of empowerment actors (Darwanto, 2011).

\section{Theoretical approach}

This study analyses an information innovation implemented in media based on ICT and explains how an individual as a subject (target audience) receives the innovation in terms of the way he/she perceives it and its impacts. To dig up deeper, innovation diffusion theory is used to support the facts.

In 1962, Everett Rogers managed to integrate information flow of research with diffusion theory which is later known as information diffusion theory. It was then applied to a diffusion of something other than information, which is technology, and therefore it 
is defined as innovation diffusion theory (Davis and Stanley, 2006). Diffusion is an innovation process communicated through certain channels to social system members. Communication is a process wherc participants create and share information to one another to reach the same understandings. An innovation is an idea, practice, or object which is believed as something new by each individual or other user unit (Rogers, 1995).

Further, based on information (innovation) diffusion theory, innovation process consists of a series of actions which covers:

1 most people will be aware of technology innovation through information from mass media

2 the innovations will be adopted by a very small group of innovators or early adopters

3 opinion leader learns from the early adopters and try the innovation themselves

4 when the opinion leader finds the innovation useful, they encourage their friends (opinion followers)

5 after most people have adopted the innovation, a group of laggards or late adopters make the change (Davis and Stanley, 2006).

\section{Methodology}

Participatory action research (PAR) method is applied to solve the problems in this research. The research method is put into details and elaborated based on the needs. It is equipped with a complete scheme -- clear steps, specific techniques in collecting data, its analysis, outer layer per year, and measurable indicators for observing achievements.

This research applies cluster approach which emphasises group dynamics using PAR method. This method was chosen because researcher team considers the importance of people involvement to support the programme reaching its goals. PAR requires researchers to be directly involved with local people to strengthen people capacity in designing plans, making decisions, and conducting real actions to improve the society condition (Cavestro, 2003).

The research conducted is participation action research considering gender perspectives which emphasise the involvement of the target subjects as active ones, make their experiences both men and women integrated in this research, identifies problems, and apply all findings to solve the target problems in the context of empowering research subjects. To achieve these, the research and actions should be united as series of activities which continuously work to complete actions so that problems faced by the research can be solved. Therefore, PAR method is identical to empowerment research (Mikkelsen, 2001). To reach the goals, PAR method should be supported by other methods like survey, case study, and focus group discussion (FGD).

The results of PAR method research become the foundation to build ICT-based model suitable to local people conditions, using user-centred design (UCD) approach. UCD is a development step of a system which applies certain approach to users. Consequently, the system works and interacts based on analysis results to the users. In turn, the users will apply the system in the future.

The first steps of UCD are identifying needs and establishing requirements. These steps aim to understand users by setting requirements based on their needs. Requirements 
can be defined as a statement of a product which explains how a product or system should work and act. By setting users as the foundation of requirements, it is expected that the product will be suitable and likeable. In identifying user needs, this research applies FGD method.

The next step is designing. Interactive forms of the design are based on the requirements which have been set in the previous step. The implementation of the design used is a prototype which is defined as a limited representative of a design which allows users to interact and explore in deciding suitability with the design. Basically, the prototype is divided into two continuous parts

1 low-fidelity prototyping: it is a prototype which uses different media from the final product

2 high-fidelity prototyping: it is a prototype which uses the same materials used in the final product.

Prototype that has been developed is going to be tested to users; in this context are the residents. It aims to observe how suitable it is to the analysis of results of the previous step - identifying needs and establishing requirements. The details of this process can be observed in the next step.

The last step is evaluation. At this process, if there is a case of inappropriateness between system planning and user needs, then the planning results can be revised. It turns UCD step back to the previous steps. When every step works as expected, the design can be implemented into the final product. The evaluation process can be conducted by testing the prototype by the users. It is necessary to note that designers never get it right the first time which means that step repetition in UCD cannot be avoided.

\section{$5 \quad$ Result and discussion}

At this part, the writer analyses every finding continuously to accomplish the findings through interviews, group discussions, and trainings.

\subsection{Difficulties faced by women in accessing internet}

Based on the need assessment on woman group in Kamnung Cyber, there is a tendency that women face difficulties in accessing communication technology and information, specifically the internet. This fact has been shown through interviews and group discussions.

The data collection of informants was held when there were meetings in RT 36, sub-district Patehan, such as Dasa Wisma (social gathering of women in group of ten), Arisan (regular social gathering) monthly held at the date of 6th, PKK meetings at the district level (RW). For arisan of RT, it is usually held in the mid of the month, after the date of $15 \mathrm{th}$, attended by the head of the family and starts at 20:00 pm in which it enablcs men and women to attend the meeting. The Dasa Wisma meeting is divided into two west and east. Although some activities are at district level, they are usually held in RT 36 such as PAUD (Education for Children in Early Ages) and Posyandu (United Services Post). Through the interviews, the findings are as follows: 
1 The residents of RT 36 Patehan Sub-district are Javanese and they live nearby the Palace. Patriarchal values immersed in society nearby the palace affect their attitudes and behaviours. For example, a woman is considered 'weird' if she accesses internet. A common thought is women have more suitable position when they do the house works. To change their mindset is difficult as they consider that it is good for the society. There are pros and cons among women themselves. Some women think that women are supposed to be caim, well-behaved, others are more progressive and therefore they decide to access internet. This condition seems common for some of them. Many of them think that it is taboo accessing the internet for women in Indonesia, mainly for Javanese who live within the palace surroundings.

2 Economic potentials of the residents in RT 36 have not been managed well. Many tourists both domestic and foreigners visit to shop products sold by the residents or they visit for learning batik. Some economic activities of the residents are making t-shirts, sewing batik clothes, providing food and drinks and many more. The organisers of RT 36 have encouraged the residents to take advantage of the internet to facilitate the distribution of their products. For example, by updating photos of the products, but many residents decide not to do such things. Some whose businesses are batik focus more on production and have less time in using the internet. According to the head of the residents, to organise the residents in a productive organisation is complicated and risky as it involves many people with different. interests; the result might fail and be conflicting.

3 Referring to the use of internet among women, there have been 23 families who have internet access. RT 36 is the area where internet can be accessed earlier than other areas. The residents can access the internet and they have created their websites. However, they seldom update them. In fact, they can take the advantage of the website to enable consumers obscrve, browse, and access their products. Some women who already have the internet access in their houscs are reluctant to use the internet. This situation makes the writer think that the proglamme possibly faces difficulties when it directly targets women to use internet and promote their businesses through internct. Therefore, it is necessary to provide adjustment to women as the target subjects.

Based on the data, to make the programme designed by the researcher team and resident programme of RT 36 suitable, the adjustment made is the use of internet to support business activities for women is no longer the priority. What is more important is to make the residents prosperous although they have not used internet to facilitate their business activities. Besides, the internet access set in their area is not simply used for fun.

To strengthen the findings, the writer exposes data gained through group discussions. The group discussion had 21 participants - 20 women and one man from Kampung Cyher. From this discussion, the writer gained the map of internet spread and business owning. Besides, it also reveals who owns a computer or laptop as the hardware to access the internet. The results of the characteristic respondent mapping are reported in Table 2. 
Table 2

Owning internet access

\begin{tabular}{|c|c|c|c|}
\hline \multirow{2}{*}{ No. } & \multirow{2}{*}{ Name } & \multicolumn{2}{|c|}{ Owning } \\
\hline & & Computer/laptop & Internet \\
\hline 1 & Sabar & - & - \\
\hline 2 & Sukirman & V & V \\
\hline 3 & LodEa & V & - \\
\hline 4 & Sri Kadarwati & - & - \\
\hline 5 & Utami Dewi & V & v \\
\hline 6 & Tien Widarto & $\mathrm{v}$ & V \\
\hline 7 & Jumiyo & V & - \\
\hline 8 & Musiyati & v & V \\
\hline 9 & Sarjilah & - & - \\
\hline 10 & Muji & - & - \\
\hline 11 & Tanti & V & V \\
\hline 12 & Jiah & - & - \\
\hline 13 & Th. Rina Pratini & V & V \\
\hline 14 & Sri Nonhuru & V & V \\
\hline 15 & Ny. Supitar & v & V \\
\hline 16 & Sri Hastuti & V & - \\
\hline 17 & Y. Sri Hartanti & - & - \\
\hline 18 & Mujilan & V & - \\
\hline 19 & Harti & - & - \\
\hline 20 & Mujiah & - & - \\
\hline 21 & Dian Kristanti & $\mathrm{V}$ & V \\
\hline \multicolumn{2}{|c|}{ Total number } & 13 & 9 \\
\hline \multicolumn{2}{|c|}{ Percentage } & $61 \%$ & $42 \%$ \\
\hline
\end{tabular}

Source: Herawati et al. (2013)

Based on the data, it is obscrved that from 21 residents of Kampung Cyber who joined the group discussion, $61 \%$ have computers or laptops and $42 \%$ havc internel conncetion. Other findings are as follows,

1 Women in Kampung Cyber do not have enough time to learn about computers as they have regular routines as a housewife and some of them have busincss activities.

2 In many families, computers are mostly used by children for doing the assignments or playing games. Some common expressions said by mothers are Mboke ngalah let the mother withdraw for the sake of her children) or wong tuwa rasah sinau komputer, mending masak trus ngumbahi (no need for the elder to learn how to use computers, it is better for them to cook and wash the laundry). Not only children, but fathers take their time in accessing internet and therefore mothers have less chance. 
3 Some mothers expressed their reluctance in learning computer as they think it is easier to use hand phones for communication than computers. This is related with opinions that the computer is associated with Facebook, e-mail, chatting to communicate with people for pleasure or simply killing the time.

4 Some mothers have not fully understood the advantages of computers so that fathers and children take maximum use of computer.

5 In terms of learning capacity, it is observed that the abilities to operate computers are various. It is shown from expressions such as Ndemok wae, urung dong (just touching, not yet knowing how to use it), or Mbukak password lom bias (not knowing how to use a password to open the computer).

6 The timetable for training has been adjusted based on the residents' activities as they said Ibu-ibu tidak ada yang menganggur (mothers have no idle time) as they run their business and manage the houses.

7 Mothers are interested in joining computer training to be more progressive, for example, to ease them to make invitations, sell goods, design products, communicate with others and etc.

8 Some suggestions from them for the programme is the team give computer trainings and prepare the assessment to sec how good they are in operating computers so it is easily observed which ones of them can or cannot operate.

9 The training is held step by step and starting by introduction, exploring abilities, and being skill full in operating computer.

\subsection{ICT training programme}

The research findings gained from PRA method is then used to build an ICT-based model adjusted with conditions of the residents using UCD apploach. Based on the findings in the levcl of need assessment, the programme designed aims at empowering women capacities in taking advantage of communicution technology and information. This part shows pictures of how the programme is implemented and of best practice found by the writer.

Early Lainings is given to women in the hasic level so they will have good progress and goes to intermediate and advance level. The learning materials for the basic level consist of:

1 introduction to computer

2 introducing technical terms of the computer stated in English

3 introduction to MS Word 2007

4 introduction to Excel 2007.

The objective of this training is stimulating women in RT 36 to operate computer skillfully and they should encourage themselves to practice at home. The training steps 
begin from the basic which covers introducing hardware to enable the operation of monitor, CPU, mouse and keyboard and introducing how to operate.

The next learning materials include computer programmes, specifically Microsoft Word and Microsoft Excel. Besides, the team also introduces computer terms in English as Microsoft uses English.

From the training, it is observed that the skills in operating computer are far from sufficient. It took a long time to understand the hardware, the instructions in English and how it works. However, the next step ran well as the participants were enthusiastic and they actively asked questions to the trainers. The communication process during the training ran well as the local language was used to operate computers, for example tunul for click the mouse, gegem for holding the mouse. The participants also played jokes during the training.

The last step of the training is introducing the internet and its advantages. It is specifically directed to the advance group as the material of the training focuses more on economic empowerment for women of Kampung Cyber RT 36. It covers entrepreneurship training and organisation development. The main goal is for women who are able to facilitate to other women. Besides, the activities can be held together within the organisation so that they can grow their motivation in learning.

\section{3 'Bakulan RT 36' web media to empower women}

The fact in Kampung Cyber shows that there is imbalance between men and women in accessing communication technology and information. Referring to gender concept, this fact is the impact of society perspectives based on social relation between men and women. It means that this unequal position in Kampung Cyber has been built by the residents and it is considered common or normal by women. This fact is affected by culture.

The residents of Kampung Cyber are those who live nearby Keraton or the palace which strongly hold Javanese tradition and one of them is the domination of patriarchy. Javanese believe that women position is under men as it is supported by values of Javanese philosophy. Proverbs such as konco wingking (partner behind), dapur-sumur-kasur (kitchen-well, on the bed), masak-macak-manak (cooking-wearing make-up-giving birth) show women the role when they got married. Their main jobs are managing their houses and husbands.

However, women in Kampung Cyber can take advantage of their economic potentials in families and communities. For those who live nearby tourist resorts, they have a series of economic activities which can be managed at home, for example, doing batik, traditional craft making, cafe owners, tailors, painters, and many more. However, their potentials cannot be optimised as they have less knowledge and information on how to develop their business activities. So far, they have marketed their products conventionally - by selling through retailers, selling for tourists who visit Tamansari, and selling to consumers as they have heard the products from someone else or known as word of mouth.

Observing that there is limitation on women to gain opportunities to develop economy capacities, it is therefore necessary to implement community literacy programmes in this area. Community literacy is a part of learning process for communities which face difficulties such as internet access to enable them gaining occupation, and capacities in public (Gabrill, 2001). Community literacy begins by 
digging up society needs to create suitable and applicable programmes. In this case, the programme is held from, for, and by society so that they can take advantage of it. Besides, it is in line with Gabril's opinion that literacy is emphasised on enlarging the networking. This has been done by community of women in Kampung Cyber. The outside layer of the programme is to build internet-based networking http://www.bakulanrt36.com.

'Bakulan RT 36' (the marketing of RT 36) is a website used to facilitate women running their productive business through internet. It provides pages consisting of detailed information related to products such as product categories, samples of products, sort of products, the seller's or business actors' profile, how to order, announcement of activities held by residents of Kampung Cyber. For example, just click a name 'Evilia Tri Wahyuni', the information comes up will be the products, the seller's data - the shop's name, address, and contacts.

This condition is a real picture of information innovation that is supposed to be adopted by certain groups and facilitated by the research team heading to changes for a better life. These changes are processes which involve perceptions, feelings, motivations, and communal behaviours (Rogers, 1995).

At the early changes, the residents tend to pay attention on values of self-awareness. It is shown when the team gave information about the use of computer and its advantages in daily life. Their feelings lead their interests to learn how to use ICT-based tools. Their involvements in computer training include the application of MS Word, MS Excel, internet access, e-mail and Facebook and its advantages for personal business. The team output is internet-based media through http://www.bakulanrt36.com which pictures society behaviours heading to changes. Every step is the implementation of a series of innovation diffusion process starting from awareness to behaviours (Davis and Stanley, 2006). Changes in this case are doing productive activities, marketing the products equipped with facilities supported by ICT. This programme enables women to gain bargaining position to develop self-capacity through economic empowerment both in the family and society.

\section{Conclusions}

Woman empowerment programme is one of the efforts to gain gender equality in society. It is a critical education to develop woman capacities in families and society as well. Innovation of information technology and communication become the foundation in designing activity programme implemented to targeted groups. Based on the need assessment on the targeted group, there are obstacles in operating the computer and accessing the latest internet-based technology. This condition is the main reason for the writer to create an empowerment programme based on problems faced and woman needs. This programme aims to build understanding - cognitively developing human resources and pragmatically transferring knowledge and skills and build organisation as a system to support woman capacities. In detail, innovation diffusion theory (Rogers, 1995) is applied to analyse the existing realities. Changes on woman community as the targeted group are heading to progressive development. The process begins from specifically understanding the targeted groups (awareness) to changes on behaviours of society in general through programme designed by the writer team. The implementation of the programme is the use of website http://www.bakulanrt36.com to facilitate their economic facilities. 


\section{References}

Cavestro, L. (2003) Participatory Rural Appraisal: Concept, Methodologies, and Techniques, Univesita Degli Studi Di Padova [online] http://www.agraria.unipd.it/agraria/master/0203/PARTICIPATORY\%20RURAL\%20APPRAISAL.pdf (accessed 23 March 2013).

Darwanto, H. (2011) Pemberdayaan Masyarakat Pedesaan Berbasiskan Masyarakat Terpencil [online] http:/www.bappenas.go.id/index.php/download_file/view/10626/2342/ (accessed 23 March 2013).

Davis, D.K. and Stanley, J.B. (2006) Mass Communication Theory: Foundations, Ferment, and Future, 4th ed., Thomson Wdsworth, USA.

Gabrill, J.T. (2001) Community Literacy Programs and the Politics of Change, State U of New York, Albany, NY.

Herawati, F.A. et al. (2013) 'Faktor yang mempengaruhi keterbatasan perempuan dalam mengakses teknologi komunikasi dan Informasi', Jurnal Penelitian Kesejahteraan Sosial, Desember, Vol. 12, No. 4, pp.327-334, ISSN 1412-6451.

Mikkelsen, B. (2001) Metode Penelitian Partispatoris dan Upaya Pemberdataan, Yayasan Obor Indonesia, Jakarta.

Mills, D.Q. (1987) 'Labor market intermediaries: an overview', Labor Market Intermedieries $A$ Special report of The National Commission for Manpower Policy, Special Report No. 22, pp.13-54, Washington, D.C.

Rhodes, J. (2003) 'Can e-commerce enable marketing in an African rural women's community based development organisation?', Informing Science Jourmal : Special Series on Community Informatics, Vol. 6, pp.157-172, Cape Town University, South Africa [online] http://www.inform.nu/Articles/Vol6/v6p157-172.pdf (accessed 23 March 2013).

Rogers, E.M. (1986) Communication Technology: The New Media and Society, Free Press, New York

Rogers, E.M. (1995) Diffusion and Innovations, 4th ed., Free Press, New York

Rosnafisah, S. et al. (2009) 'The e-business potential for home-based businesses in Malaysia: a. qualitative study', International Journal of Cyber Saciety and Education, 1 June, Vol. 2, No. 1, pp.21-36 [online] http://www.academicjournals.org/ojs2/index.php/IJCSE/article/view/521/15 (accessed 23 March 2013).

Rusman (2007) Teknologi Komunikasi Dan Informasi Dalam Pembelajaran [online] http://kurtek.upi.edu/tik/content/internet.pdf (accessed 23 March 2014).

Siddiquee, A. and Carolyn, K. (2006) 'The internet, impowerment and identity: an exploration of participation by refugec women in u community internet project in the United Kingdom (UK)', Jutrnal of Community \& Applied Social Psycology. J. Community Appl. Soc Phychol., Vol. 16, No. 3, pp.189-206 [unline] http://onlinclibrary.wilcy.com/doi/10.1002/casp.855/full (accessed 21 March 2013).

Sumodiningrat, G. (1997) Pembangunan Daerah dan Pemberdayaan Masyarakat, Bina Rena Pariwara, Jakarta.

Supriyanto, A. (2008) Pengantar Teknologi Informasi, Salemba Infotek, Jakarta. 